\title{
Magnetická rezonance stavu po infarktu myokardu u sedmiletého dítěte s reimplantací anomálního odstupu levé koronární tepny z plicnice
}

\author{
Theodor Adla, Lukáš Mikšík, Helena Bartáková*, Viktor Tomek*, Roman Gebauer*, Miloslav Roček \\ Klinika zobrazovacích metod, Fakultní nemocnice v Motole a 2. lékařská fakulta Univerzity Karlovy, *Kardiocentrum \\ a Centrum výzkumu chorob srdce a cév, Fakultní nemocnice v Motole, Praha, Česká republika
}

\begin{abstract}
Anomální odstup levé koronární tepny z plicnice je vzácná vrozená srdeční vada. $V$ české populaci se udává prevalence asi 0,01 na 1000 živě narozených dětí. ${ }^{(1)} Z$ e všech srdečních vad je výskyt $0,22 \%$. Vyskytuje se převážně izolovaně nebo méně často je sdružena s dalšími vadami (aortopulmonální okno, arteriální trunkus, defekt komorového septa). Obvykle odstupuje z levého pulmonálního sinu. S poklesem tlaku $\mathrm{v}$ plicním řečišti po narození se obrací tok v levé koronární tepně. Dochází k levo-pravému zkratu, který nebývá významný, ale dochází k nedostatečné perfuzi myokardu okysličenou krví. Následkem může být infarkt myokardu. Více než 80 \% dětí dříve umíralo v prvním roce života. V současnosti je tato vada indikací k urgentní operaci, obvykle reimplantaci levé koronární arterie do aorty. Vzácně mủže dojít po reimplantaci k získané stenóze levé koronární arterie.(2)

Zobrazení chronického ischemického postižení myokardu pomocí magnetické rezonance před zvažovanou koronární revaskularizací je u dospělých pacientů zavedenou metodou. Umožňuje
\end{abstract}

stanovit funkční parametry, poruchy kinetiky myokardu, zhodnotit klidovou perfuzi a především s pomocí pozdního nasycení myokardu stanovit rozsah subendokardiálního a transmurálního postižení myokardu, a tedy zhodnotit viabilitu svalové tkáně. ${ }^{(3)}$

U prezentované pacientky byl vrozený anomální odstup levé koronární tepny z plicnice diagnostikován ve věku tři měsíců a byla ihned provedena reimplantace levé koronární tepny do aorty. Pro trvající dysfunkci levé komory s aneurysmatem hrotu byla provedena koronarografie a zjištěna stenóza kmene levé koronární arterie. V odstupu šesti let od operace byla provedena koronarografie s nálezem uzávěru kmene levé koronární arterie a dobrého kolaterálního oběhu mezi povodím pravé a levé koronární arterie. Echokardiograficky byla zjištěna porucha kinetiky apikální části laterální stěny levé komory a hrotu (obrázek 1). Vzhledem k zvažované operaci (aortokoronární bypass $\mathrm{s}$ resekcí aneurysmatu levé komory) byla doporučena magnetická rezonance.
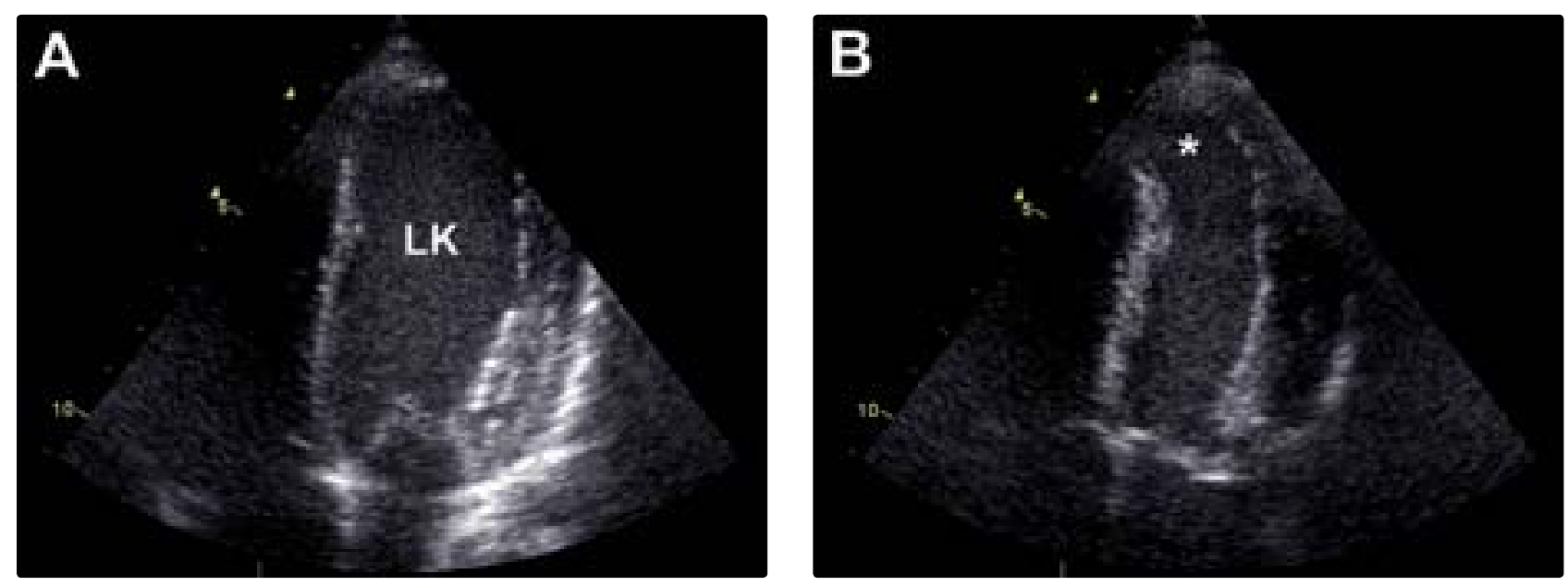

Obrázek 1 Echokardiografické zobrazení - apikální čtyřdutinová projekce v diastole (A) a systole (B); apikoseptální aneurysma levé komory (*), fibroelastóza papilárních svalů mitrální chlopně

LK - levá komora

Adresa: MUDr. Theodor Adla, Klinika zobrazovacích metod, FN Motol a 2. LK UK, V úvalu 84, 15006 Praha 5, Česká republika, e-mail: theodor.adla@ Ifmotol.cuni.cz 

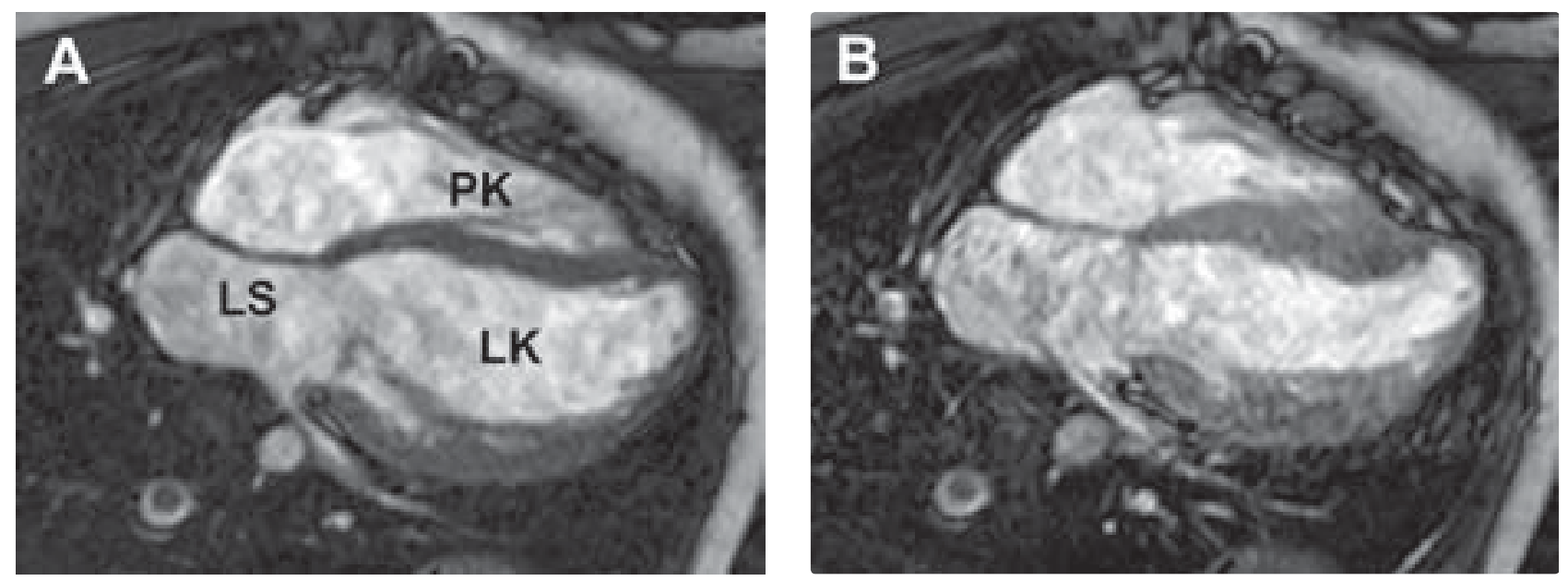

Obrázek 2 Zobrazení magnetickou rezonancí ve čtyřdutinové rovině kinematickou sekvencí bFFE (balanced fast field echo) v diastole (A) a systole (B); dyskineze hrotu levé komory s omezeným systolickým zesílením myokardu

PK - pravá komora, LS - levá síň, LK - levá komora
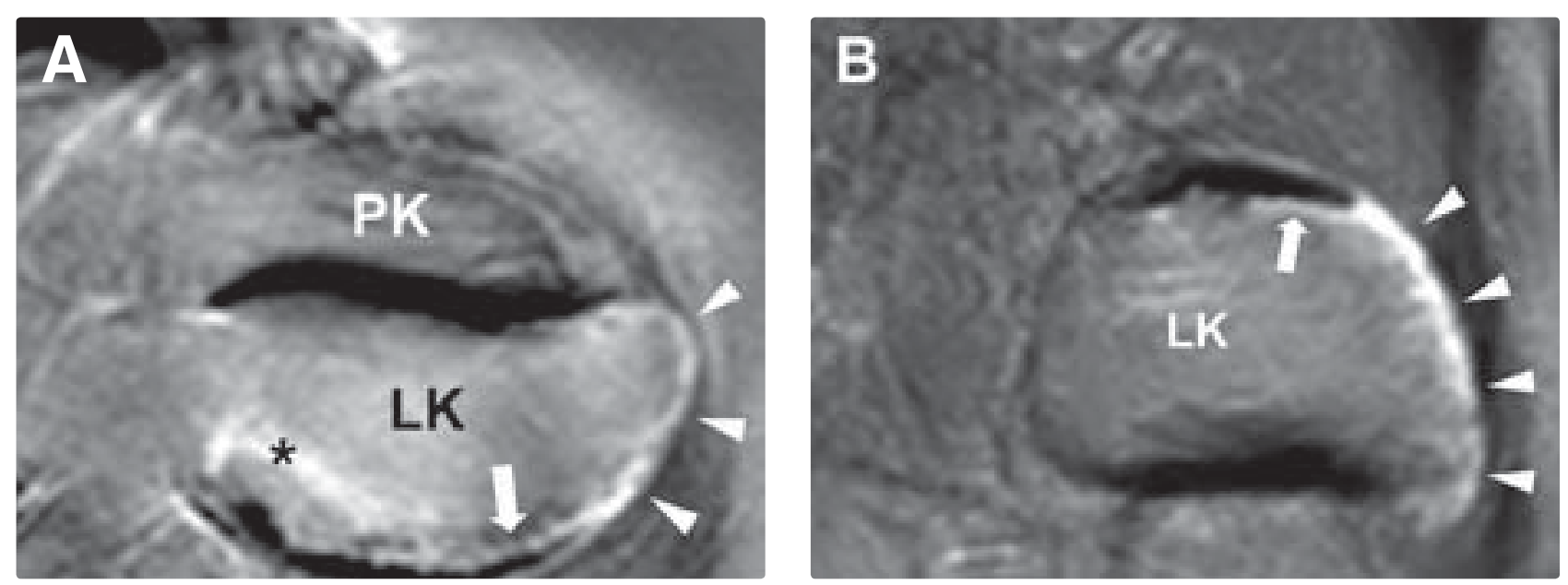

Obrázek 3 Zobrazení magnetickou rezonancí pozdního nasycení

A. Ve čtyřdutinové rovině zobrazeno transmurální postižení myokardu v oblasti hrotu (hlavy šipek), kde je nasycena celá šíře stěny, ve střední části laterální stěny je zobrazena subendokardiální jizva (šipka), pozdní nasycení je pozitivní i v oblasti zadního papilárního svalu (*)

B. V dlouhé ose je zachyceno transmurální postižení hrotu a hrotové části levé komory (hlavy šipek) a subendokardiální postižení střední části přední stěny (šipka)

PK - pravá komora, LK - levá komora

Vyšetření srdce magnetickou rezonancí vyžaduje dobrou spolupráci pacienta s nutností opakovaně zadržovat dech na 10-20 sekund. Při vyšetření dětí, kdy nelze počítat $s$ jejich spoluprací, je často nutné uvést pacienta do celkové anestezie. Vyšetření tedy bylo synchronizováno jak s EKG, tak s dechem. Přestože obrazy trpí určitými pohybovými artefakty, vyšetření bylo plně diagnostické (obrázky 2 a 3 ).

\section{Literatura}

1. Šamánek M. Etiologie a výskyt vrozených srdečních vad. V: Chaloupecký V, et al. Dětská kardiologie, Praha: Galén, 2006:117-20.

2. Chaloupecký V. Anomálie koronárních arterií. V: Chaloupecký V, et al. Dětská kardiologie. Praha: Galén, 2006:259-64.

3. Dymarkowski S, Bogeart J, Ni Y. Ischemic heart disease. In: Bogeart J, et al. Clinical Cardiac MRI. Berlin, Heidelberg: Springer-Verlag, 2005:173-216. 